Tropical Journal of Pharmaceutical Research March 2021; 20 (3): 573-578

ISSN: $1596-5996$ (print); 1596-9827 (electronic)

(C) Pharmacotherapy Group, Faculty of Pharmacy, University of Benin, Benin City, 300001 Nigeria.

Original Research Article

http://dx.doi.org/10.4314/tjpr.v20i3.19

\title{
Effect of mono- and dual frequency power ultrasound assisted enzymolysis on the degree of hydrolysis and ACE inhibitory activity of Stevia protein hydrolysates
}

\author{
Mohammed Abdalbasit A Gasmalla ${ }^{1,2}$, Abubakr Musa ${ }^{1,3}$, Faisal N Awad ${ }^{1}$, \\ Habtamu Admassu', Haile $\mathrm{Ma}^{4 *}$ \\ ${ }^{1}$ School of Food and Biological Engineering, Jiangsu University, 301 Xuefu Road, Zhenjiang, Jiangsu 212013, China, \\ ${ }^{2}$ Department of Nutrition \& Food Technology, Faculty of Science and Technology, Omdurman Islamic University, PO Box 382, \\ 14415 Khartoum, ${ }^{3}$ Sugar Institute, University of Gezira, PO Box 20, Wad madani, Sudan, ${ }^{4}$ Department of Food Process \\ Engineering, Addis Ababa Science and Technology University, PO Box 16417, 1000 Addis Ababa, Ethiopia
}

*For correspondence: Email: mhl@ujs.edu.cn; moh_8282@hotmail.com; Tel: +86 511 88790958; Fax: +86 51188790958

Sent for review: 4 December 2019

Revised accepted: 18 February 2021

\begin{abstract}
Purpose: To study the effects of ultrasound pretreatment at different frequencies and working modes, including mono frequency ultrasound (MFU) and dual-frequency ultrasound (DFU), on the degree of hydrolysis (DH) and angiotensin-I-converting enzyme (ACE) inhibitory effect of Stevia protein (SP).

Methods: Protein from Stevia leaves was extracted by water (50 g suspended in $1000 \mathrm{~mL}$ ). The hydrolysis of stevia protein extract (SPE) was carried out using alcalase at $5 \%$ enzyme substrate (E/S) ratio. A study was then carried out to investigate its microstructure and morphology using scanning electron microscopy (SEM).

Results: The results showed that ultrasound pretreatment did not increase $D H$ of SP significantly $(p>$ 0.05). However, the highest ACE inhibitory activity of stevia protein hydrolysate was obtained at DFU level (20/50 KHz). Overall, ultrasonic frequency mode had a significant influence on ACE inhibitory activity.

Conclusion: The frequency selection of ultrasound pretreatment of SP is essential for the preparation of ACE inhibitory peptide.
\end{abstract}

Keywords: Alcalase, Hydrolysis, Ultrasound frequency, Stevia protein, ACE inhibitory peptide

This is an Open Access article that uses a fund-ing model which does not charge readers or their institutions for access and distributed under the terms of the Creative Commons Attribution License (http://creativecommons.org/licenses/by/4.0) and the Budapest Open Access Initiative (http://www.budapestopenaccessinitiative.org/read), which permit unrestricted use, distribution, and reproduction in any medium, provided the original work is properly credited.

Tropical Journal of Pharmaceutical Research is indexed by Science Citation Index (SciSearch), Scopus, International Pharmaceutical Abstract, Chemical Abstracts, Embase, Index Copernicus, EBSCO, African Index Medicus, JournalSeek, Journal Citation Reports/Science Edition, Directory of Open Access Journals (DOAJ), African Journal Online, Bioline International, Open-J-Gate and Pharmacy Abstracts

\section{INTRODUCTION}

In recent years, the demand for protein has increased due to increase in global population [1]. It is estimated that nearly $25 \%$ of the world population lack a suitable protein supply [2].

Plant proteins have been studied for likely incorporation into formulated food, because of the limited availability and soaring costs of animal proteins [3]. Stevia rebaudiana Bertoni, a herbal medicine belonging to the Asteraceae family originated from Latin America. Recently, it is growing widely in different countries including Japan, Korea, and China as a commercial plant [4]. Studies have shown that dried stevia extract is rich in flavonoids, green pigment, amino acids, and other essential nutrients. It has been certified 
that stevia rebaudiana leaves contain a considerable amount of protein [5].

Stevia has potential in the tranportation of medicines around the body and may also help to control blood sugar by modulating insulin generation and sensitivity [6]. Hypertension can cause stroke, chronic kidney disease, heart failure and many kinds of problems [7]. It is well known that ACE is responsible for hormones that help control our blood pressure. It converts the hormone angiotensin $I$ to the active vasoconstrictor angiotensin II and inactivates bradykinin. ACE indirectly raises blood pressure by causing blood vessels to constrict [8].

Studies have shown that plant protein is rich in bioactive peptides which attracts a lot of scientists. In addition, hydrolysis by enzymes is largely used in the production of bioactive peptides from different food sources $[9,10]$. By enzymatic hydrolysis, the physical and chemical properties as well as the micro structure of proteins can be changed.

There are a number of different ultrasound parameters that can increase accessibility of proteolytic enzymes to peptide bonds such as ultrasound frequency [11]. Changes in protein configuration expose more hydrogen bonds during ultra-sonication [12]. However, advanced technologies have been applied to enhance the hydrolysis of protein, functional and bioactive peptides [12,13]. Consequently, the purpose of this research was to examine the effect of single and dual- ultrasound frequency on the $\mathrm{DH}$ and ACE inhibitory of stevia protein hydrolysates.

\section{EXPERIMENTAL}

\section{Materials}

Stevia rebaudiana Bertoni leaf powder was purchased from the (Yancheng Xiaguang Co. Jiangsu, China) in September 2018. It was then kept dried in polyethylene bags at $4{ }^{\circ} \mathrm{C}$ for further use. Alcalase with an activity of $150,000 \mathrm{U} / \mathrm{mL}$ was obtained from Novozymes Biotechnology Co. Ltd. (Shanghai, China). All other reagents used in this study were of analytical grade.

\section{Stevia protein extraction}

Stevia protein was extracted according to the method described by Xue et al [14] with some modification. The suspension was centrifuged at $4000 \mathrm{~g}$ for $20 \mathrm{~min}$ and Iyophilization for further analysis using a freeze-dryer (ALPHA 1-2, Martin Christ Inc., Germany).

\section{Ultrasound treatment with single frequency ultrasound (SFU)}

In this study, ultrasonic frequency can work in single and dual-band. Ultrasound treatment with single frequency (SFU) was at 20, 28, 35, 40 and $50 \mathrm{KHz}$. The output power was $80 \mathrm{~W} / \mathrm{L}$ with substrate $50 \mathrm{~g} / \mathrm{L}$ at $30{ }^{\circ} \mathrm{C}$. The degree of hydrolysis $(\mathrm{DH})$ and angiotensin convert enzyme activity were selected to optimize ultrasound pretreatment parameters. The stevia protein without ultrasound under the same conditions was set as control.

\section{Ultrasound treatment with dual frequency ultrasound (DFU)}

The same different model frequency power ultrasound equipment was used to process the sample in this study. The instrument was equipped with four frequency generators $(20,28$, 35 and $40 \mathrm{kHz}$ ). In this study dual-frequency simultaneous ultrasound (DFU) with 20/28, $20 / 35,20 / 40$ and $20 / 50 \mathrm{kHz}$ was chosen for the sample treatments. The other pretreatment parameters were set and carried out under the same conditions of ultrasound treatment with single frequency ultrasound.

\section{Enzymolysis of Stevia protein (SP)}

Before enzymatic hydrolysis, the temperature and $\mathrm{pH}$ of SP mixture were increased up to $50^{\circ} \mathrm{C}$ and 9.0 respectively. Then $5 \%(E / S)$ alcalase was added to begin the reaction. During reaction 1 $\mathrm{mol} / \mathrm{L} \mathrm{NaOH}$ continuously added for remaining $\mathrm{pH}$ at 9.0. The enzymolysis time was 90 min and at the end of reaction, the mixture was heated $\left(100^{\circ} \mathrm{C}\right.$ for $\left.10 \mathrm{~min}\right)$ to inactivate alcalase. Finally, the hydrolysates were centrifuged at $12000 \times \mathrm{g}$ for $15 \mathrm{~min}$ after cooling to room temperature.

\section{Determination of the degree of hydrolysis (DH)}

The degree of hydrolysis $(\mathrm{DH})$ was calculated according to the $\mathrm{pH}$-stat method described by Adler-Nissen [15] using Eqs 1 and 2.

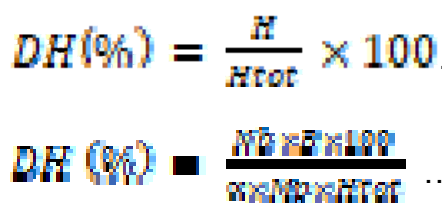

where $\mathrm{Nb}$ is a normality of sodium hydroxide (mol/L); $B$ is base (sodium hydroxide) consumption (mL); Mp is SP mass $(\mathrm{g})$; $\mathrm{H}_{\text {tot }}$ is the total content of peptide bonds, which is 9.2 $\mathrm{mmol} / \mathrm{g}$ protein; $\alpha$ is the average degree of 
dissociation of the a-amino groups that is related to the $\mathrm{pK}$ of the amino groups at a particular $\mathrm{pH}$ and temperature, which is 0.99 at $\mathrm{pH} 9.0$ and 50 ${ }^{\circ} \mathrm{C}$.

\section{Measurement of ACE inhibitory activity}

The measurement of ACE-inhibitory activity of the stevia hydrolysate was based on the assay described by Vermeirssen et al [16] Briefly, $50 \mu \mathrm{L}$ of borate buffer (1.0 mM FAPGG, $80 \mathrm{mM}$ HEPES, $0.1 \mathrm{M}$ borate buffer, $300 \mathrm{mM} \mathrm{NaCl}, \mathrm{pH}$ 8.0) and $40 \mu \mathrm{L}$ of stevia hydrolysate were mixed in microtiter plate wells, and using $40 \mu$ of distilled water instead of stevia hydrolysate as control.

To initiate the reaction $20 \mu \mathrm{L}$ of ACE $(0.1 \mathrm{U} / \mathrm{mL})$ was added to the solution and kept at $37{ }^{\circ} \mathrm{C}$ for $30 \mathrm{~min}$ in an incubator (SPX-250B, C. G. Co. Ltd., Jiangsu, China). The reduction in absorbance was read at $340 \mathrm{~nm}$. ACE-inhibitory (I) activity was calculated as shown in Eq 3:

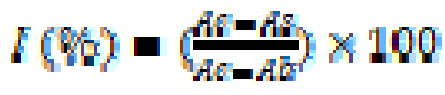

ACE-inhibitory activity was measured in triplicate at five concentrations. where $I$ is the ACE inhibitory activity (\%), $A \mathrm{c}$ is the absorbance of the control group without protein hydrolysates, $A \mathrm{~b}$ is the absorbance of the blank group without ACE, and $A S$ is the absorbance of the sample group with $\mathrm{ACE}$ and protein hydrolysates.

\section{Determination of soluble protein yield}

To measure the soluble protein content in each experiment, the folin phenol procedure was applied as described by Mokhtar et al [17]. The absorbance of protein in the reactor was analyzed using a spectrophotometer (T6, Shanghai Purkinje General Instrument Co., China) at $680 \mathrm{~nm}$. The yield $(Y)$ of protein was determined as in Eq 4.

$$
Y(\%)=\frac{c y}{m} \times 100
$$

where, y represents the soluble protein yield (\%), $\mathrm{C} \mathrm{s}$ is the soluble protein concentration in the stevia's protein solution ( $\mathrm{mg} / \mathrm{L}), \mathrm{V}$ is the volume of the stevia protein solution $(L)$, and $m$ is the protein content of sample $(\mathrm{mg})$.

\section{Amino acid determination}

Amino acid profiles of stevia protein samples were determined using RP-HPLC system according to the previous method of Li et al [18].

\section{Scanning electron microscopy (SEM) analysis}

Stevia protein hydrolysate was observed under SEM (Hitachi - SU1510 - Japan) for morphological characterization. Dried sample particles were fixed on a specific carbon film support, and their shape and surface characteristics were observed using a gaseous secondary electron detector GSED in environmental mode (ESEM).

\section{Statistical analysis}

Analysis of variance (ANOVA) was used in this study to compare the influence of various pretreatments of ultrasound of stevia protein at level $p<0.05$. All statistical analyses were conducted with SPSS 17.0 software (IBM Corporation, USA).

\section{RESULTS}

Effects of ultrasound pretreatment with different frequencies and working modes on DH

Figures $1 \mathrm{~A}-\mathrm{B}$ show the $\mathrm{DH}$ of SP. The results indicate that all the ultrasound pretreatment did not improve the $\mathrm{DH}$ value of SP significantly $(p>0.05)$. Figure 1 A shows the effects of the MFU pretreatment operating at 20, $28,35,40$ and $50 \mathrm{kHz}$ on the $\mathrm{DH}$ of SP. Figure 1 $B$ shows the effects of DFU of all the frequency combinations $(20 / 28,20 / 35,20 / 40,20 / 50) \mathrm{kHz}$ on the $\mathrm{DH}$ of SP.

Angiotensin-l-converting enzyme inhibitory activity of SP hydrolysate was pretreated with MFU and DFU are shown in Figure $2 \mathrm{~A}$ and $\mathrm{B}$ respectively. The ultrasound pretreatment increased ACE inhibitory effect of SP hydrolysate significantly $(p<0.05)$.

\section{Protein yield}

The protein content obtained in stevia is $18.4 \%$ and the protein yield at optimal extraction points of ultrasonic treatments was $56 \pm 2.91 \%$.

\section{Amino acid profile}

Amino acids composition is shown in Table 1. The results reveal that the content of essential amino acids have been almost higher than those recommended by $\mathrm{FAO}$ and $\mathrm{WHO}$.

Trop J Pharm Res, March 2021; 20(3): 575 

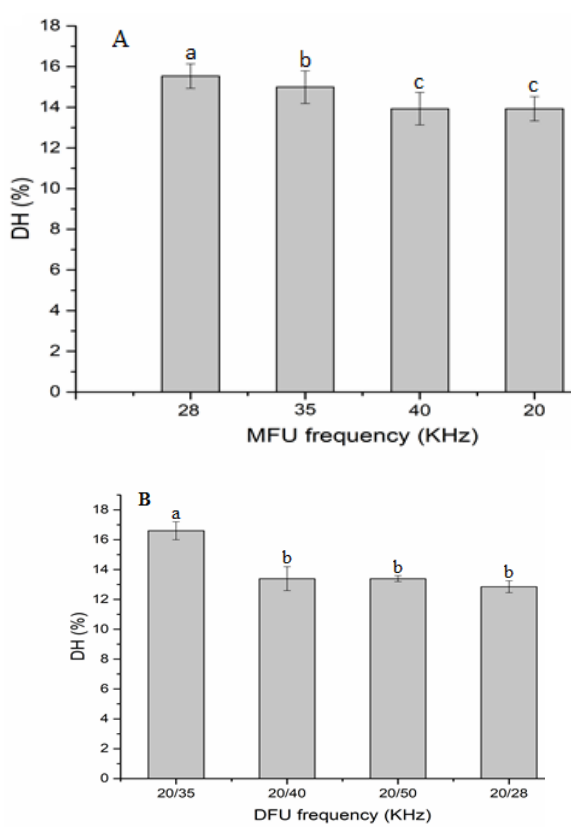

Figure 1: Effect of ultrasound pretreatment at different frequencies and working modes on the $\mathrm{DH}$ of SP hydrolysate. (A) MFU and (B) DFU. Results are represented as mean of three determinations \pm standard deviation. Means with different superscripts are significantly different $(p<0.05)$
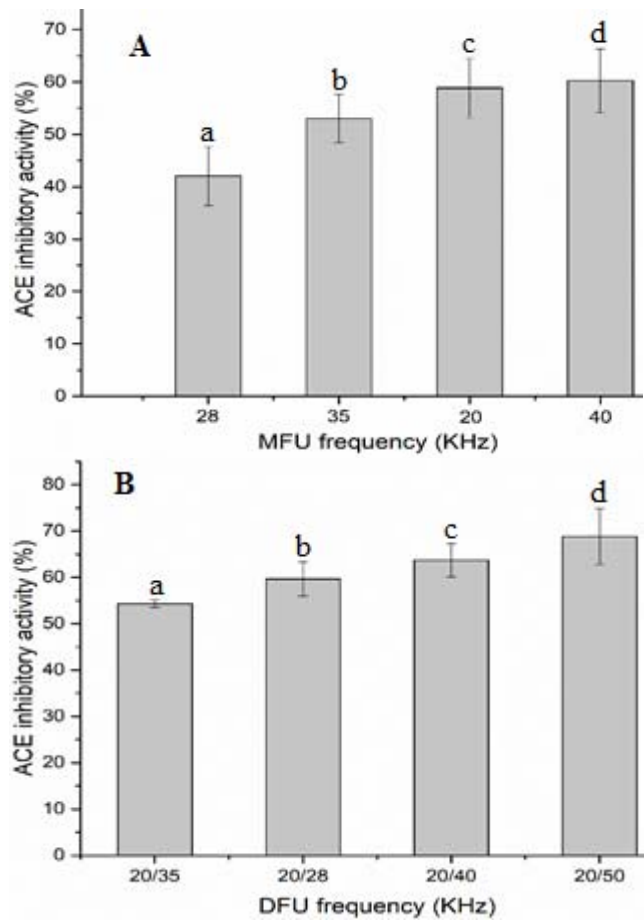

Figure 2: Effect of ultrasound pretreatment at different frequencies and working modes on the ACE inhibitory rate of SP hydrolysate. (A) MFU and (B) DFU Results are represented as mean of three determinations \pm standard deviation. Means with different superscripts are significantly different $(p<0.05)$

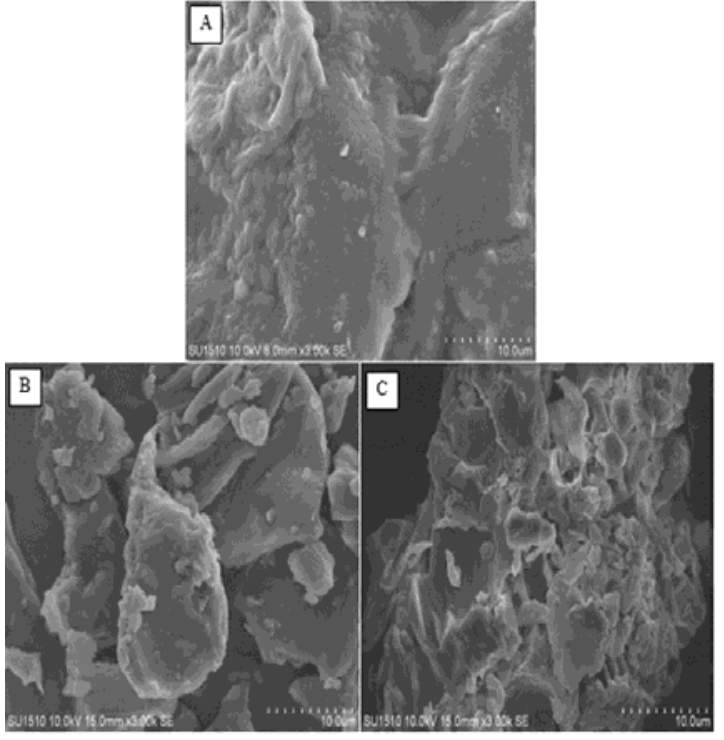

Figure 3: Effects of ultrasound pretreatment with different frequencies and working modes on the microstructure of SP. (A) Native SP; (B) MFU pretreated SP (28 kHz ultrasound working mode); (C) DFU pretreated SP $(20 / 35 \mathrm{kHz}$ ultrasound working mode)

Table 1: Amino acid composition of Stevia rebaudiana Bertoni (g/100g protein) $)^{a}$

\begin{tabular}{|c|c|c|}
\hline $\begin{array}{l}\text { Essential amino } \\
\text { acid (EAA) }\end{array}$ & Value & $\begin{array}{c}\text { Recommended } \\
\text { level }^{b}\end{array}$ \\
\hline Histidine & $0.43 \pm 0.09$ & 0.18 \\
\hline Therionine & $0.53 \pm 0.13$ & 0.34 \\
\hline Arginine & $0.80 \pm 0.19$ & 0.35 \\
\hline Valine & $0.90 \pm 0.11$ & 0.35 \\
\hline Methionine & $0.09 \pm 0.06$ & 0.25 \\
\hline Phenyl alanine & $0.80 \pm 0.06$ & 0.63 \\
\hline Isoleucine & $0.57 \pm 0.12$ & 0.28 \\
\hline Leucine & $1.28 \pm 0.05$ & 0.66 \\
\hline Lysine & $0.83 \pm 0.06$ & 0.58 \\
\hline \multicolumn{3}{|c|}{ Non-essential amino acid content $(\mathrm{g} / 100 \mathrm{~g})$ protein) } \\
\hline Aspartate & $0.03 \pm 0.01$ & - \\
\hline Glutamine & $0.03 \pm 0.01$ & - \\
\hline Serine & $0.19 \pm 0.07$ & - \\
\hline Glycine & $0.01 \pm 0.02$ & - \\
\hline Alanine & $0.05 \pm 0.01$ & - \\
\hline Tyrosine & $0.01 \pm 0.01$ & - \\
\hline Proline & $0.04 \pm 0.01$ & - \\
\hline Cystine & ND & - \\
\hline \multicolumn{3}{|c|}{ Amino acid (\%) with different characteristics ${ }^{c}$} \\
\hline Basic & $2.06 \pm 0.14$ & - \\
\hline Acidic & $0.06 \pm 0.01$ & - \\
\hline Hydrophobic & $3.73 \pm 0.06$ & - \\
\hline Uncharged Polar & $0.74 \pm 0.06$ & - \\
\hline
\end{tabular}

a All values given are means of three determinations means \pm standard deviation. ${ }^{b}$ Lists of FAO/WHO: Daily requirements for humans. c Basic: Lysine, arginine, histidine, acidic: aspartic acid, glutamic acid, hydrophobic: alanine, isoleucine, leucine, methionine, phenylalanine, proline, valine, uncharged polar: glycine, serine, threonine, tyrosine, cysteine vbbv 


\section{Scanning electron micrographs (SEM)}

Stevia rebaudiana bertoni leaves were scanned for structural analyses by scanning electron microscopy and compared with control.

\section{DISCUSSION}

The effect of ultrasound pretreatment on the ACE inhibitory activity of SP is significantly increased $(p<0.05)$ compared with the untreated sample by $47.67,5.55,33.17$, and $51.12 \%$ for 20,28 , $35,40 \mathrm{kHz}$ respectively. From the results shown in figure $2 \mathrm{~A}, 40 \mathrm{kHz}$ ultrasound frequency was the highest activity. This phenomenon explains changes of the protein that occur by surface hydrophobicity. On the other hand, DFU was also increased significantly $(p<0.05)$ by $72.67 \%$ and reached the peak at the frequency combinations of $20 / 50 \mathrm{kHz}$ compared with the untreated one. The molecular unfolding of the Stevia protein that affected by ultrasound increases its surface hydrophobicity, which enabled the release of ACE inhibitory peptides during the enzymatic hydrolysis. It indicates that the ACE inhibitory activity improved significantly by the DFU compared with the MFU. It can be concluded from the results that the ultrasound pretreatment increases the ACE inhibitory effect of SP hydrolysate. Stevia contained $18 \%$ protein. However, there was a significant $(p<0.05)$ increase of protein $(56 \pm 2.91 \%)$ in the protein extract. As documented, the existence of the protein-lipid complex make disrupts protein hydrolysis $[21,22]$. Therefore, the differences in the total protein and protein yield after extraction might be caused by the removal of fat and impurities during the extraction, which results in a stable protein which makes it a proteinacious source. The composition of amino acids in SP is presented in Table 1. The amount of two amino acids (phenyl alanine and lysine) were close-to those recommended by FAO and WHO for daily adult- as well as non- essential amino acids (aspartate, serine, glutamine proline, glycine, alanine, cystine and tyrosine).

This indicates that Stevia could be used as a good source of essential amino acids which can be factors to maintain a good health. Similar results were obtained by Mohammad et al [23] who reported that out of twenty amino acids, nine amino acids were identified as glutamic acid, aspartic acid, lysine, serine, isoleucine, alanine, proline, tyrosine and methionine in stevia leaves. The total amino acid content (TAA) of the sample was calculated to be $6.23 \mathrm{~g} / 100 \mathrm{~g}$. Leucine was the most abundant amino acid while methionine was the least one. The ultrasound pretreatment samples were examined for structural analyses by SEM and compared with control. As shown in Figure 3, the surfaces of SP showed significant variations in size and shape when viewed by SEM. As a comparison, the surface of control sample Figure $3 \mathrm{~A}$, native SP was rough, taking on island shape and was aggregated due to the intensity of hydrophobicity between the protein molecules. Treated ultrasound samples (Figure B and $C$ ) have a porous structure which explained its excellent rehydration property compared to that of control. The reasons for differences in their surfaces could be the changes in interconnection and intermolecular distance caused during the process [24]. It was observed that there was complete parenchyma without any significant destruction on cell walls but with slight ruptures on the surfaces of native stevia protein. Similarly initiated cell rupture and damage, allowed for more of the protein from the powder to be extracted. Further study is needed to assess the yield of total protein between two samples.

\section{CONCLUSION}

From this study, we can conclude that stevia protein can be used as a material for generating protein hydrolysate due to its high content of protein. Arginine, valine, methionine, phenyl alanine and lysine are the major amino acid contents of the SP. Furthermore, all the ultrasound pre-treatment including single frequency and dual frequency have significantly influenced the pre-treatment of SP. It is important to notice that stevia protein inhibits the activity of ACE which has been our study's objective. This finding is due to functional properties of stevia protein which can make it easy to use in food and pharmaceutical industry and may potentially serve as a good source of desirable peptide and amino acids.

\section{DECLARATIONS}

\section{Acknowledgement}

The authors would like to acknowledge the support from Post-doctoral Program in Jiangsu University, China.

\section{Conflict of interest}

No conflict of interest is associated with this work.

\section{Contribution of authors}

We declare that this work was done by the authors named in this article and all liabilities 
pertaining to claims relating to the content of this article will be borne by the authors.

\section{Open Access}

This is an Open Access article that uses a funding model which does not charge readers or their institutions for access and distributed under the terms of the Creative Commons Attribution License (http://creativecommons.org/licenses/by/ 4.0) and the Budapest Open Access Initiative (http://www.budapestopenaccessinitiative.org/rea d), which permit unrestricted use, distribution, and reproduction in any medium, provided the original work is properly credited.

\section{REFERENCES}

1. Villanueva A, Vioque J, Sanchez-Vioque R, Clemente A, Bautista J, Millan F. Production of an extensive sunflower protein hydrolysate by sequential hydrolysis with endo- and exo-proteases. Grasasy Aceites 1999; 50(6): 472-476.

2. Azam S, Khan Z, Ahmad B, Khan I, Ali J. Production of single cell protein from orange peels using Aspergillus niger and Saccharomyces cerevisiae. Glob J Biotechnol Biochem 2014; 9(1): 14-18.

3. Claver IP, Zhou H. Enzymatic hydrolysis of defatted wheat germ by proteases and the effect on the functional properties of resulting protein hydrolysates. $J$ Food Biochem. 2005; 29(1): 13-26.

4. Rai C, Majumdar GC, De S. Primary Clarification of Stevia Extract: A Comparison Between Centrifugation and Microfiltration. Separ Sci Technol 2013; 48: 113121.

5. Gasmalla MAA, Yang $R$, Hua $X$. Stevia rebaudiana Bertoni: An alternative sugar replacer and its application in food industry. Food Eng Rev 2014; 6(4): 150-162.

6. Yildiz-Ozturk E, Tag O, Yesil-Celiktas O. Subcritical water extraction of steviol glycosides from Stevia rebaudiana leaves and characterization of the raffinate phase. J Supercrit Fluids 2014; 95: 422-430.

7. Chalamaiah $M, Y u W, W u$ J. Immunomodulatory and anticancer protein hydrolysates (peptides) from food proteins: a review. Food Chem 2017; 245: 205-222.

8. Chen L, Chen J, Ren J. Effects of ultrasound pretreatment on the enzymatic hydrolysis of soy protein isolates and on the emulsifying properties of hydrolysates. J Agric Food Chem 2011; 59(6): 26002609.

9. Pradal D, Vauchel P, Decossin S, Dhulster P, Dimitrov K. Kinetics of ultrasound-assisted extraction of antioxidant polyphenols from food by-products: Extraction and energy consumption optimization. Ultrason Sonochem 2016; (32): 137-146.
10. Wang B, Meng T, Ma $H$, Zhang $Y$, Li Y, Jin J, Ye X. Mechanism study of dual-frequency ultrasound assisted enzymolysis on rapeseed protein by immobilized Alcalase. Ultrason Sonochem 2016; 32: 307-313.

11. Alzorqi I, Ketabchi MR, Sudheer S, Manickam S. Optimization of ultrasound induced emulsification on the formulation of palm-olein based nanoemulsions for the incorporation of antioxidant beta-d-glucan polysaccharides. Ultrason Sonochem 2016; 31: 71-84.

12. Reboredo-Rodríguez P, Rey-Salgueiro L, Regueiro J, González-Barreiro C. Cancho-Grande B,Simal-Gándara J. Ultrasound- assisted emulsification-microextraction for the determination of phenolic compounds in olive oils. Food Chem 2014; 150: 128-136.

13. Cheng Y, Liu Y, Wu J, Donkor PO, Li T, Ma H. Improving the enzymolysis efficiency of potato protein by simultaneous dual-frequency energy-gathered ultrasound pretreatment: Thermodynamics and kinetics. Ultrason Sonochem 2017; 37: 351-359.

14. Xue Y, Yunliang L, Suyun L, Ayobami O O, Siyu Ruan, Yucheng $W$, Shanfen $\mathrm{H}$, Haile Ma. Effects of ultrasound pretreatment with different frequencies and working modes on the enzymolysis and the structure characterization of rice protein. Ultrason Sonochem 2017; 38: 19-28.

15. Adler-Nissen J. Enzymic Hydrolysis of Food Proteins, Elsevier Applied Science Publishers, 1986.

16. Vermeirssen V, Van Camp J, Verstraete W (2002) Optimisation and validation of an angiotensin-converting enzyme inhibition assay for the screening of bioactive peptides. J Biochem Biophys Methods 51: 75-87.

17. Mokhtar D, Ronghai H, Haile M, Abubakr M, Optimization of ultrasound assisted extraction of protein from sunflower meal and its physicochemical and functional properties. J Food Process Eng 2018; 41(5):

18. Li S, Yang X, Zhang $Y, M a H$, Liang $Q, Q u W$, He R, Zhou C, Mahunu G K. Effects of ultrasound and ultrasound assisted alkaline pretreatments on the enzymolysis and structural characteristics of rice protein, Ultrason Sonochem. 2016; 31: 20-28.

19. Nilsang S, Lertsiri S, Suphantharika M, Assavanig A. Optimization of enzymatic hydrolysis of fish soluble concentrate by commercial proteases. I Food Eng 2005; 70: 571-578.

20. Slizyte R, Rustad T, Storro I. Enzymatic hydrolysis of cod (Gadus morhua) by-products: Optimization of yield and properties of lipid and protein fractions. Process Biochem 2005; 40: 3680-3692.

21. Mohammad MR, Mohammad UD, Sher MM, Habib AN, lqbal $A Q$. In vitro clonal propagation and biochemical analysis of field established Stevia rebaudiana Bertoni. Pak J Bot 2007; 39: 2467-2474.

22. Pinela J, Barros L, Carvalho AM, Ferreira I. Influence of the drying method in the antioxidant potential and chemical composition of four shrubby flowering plants from the tribe Genisteae (Fabaceae). Food Chem Toxicol 2011; 49: 2983-2989.

Trop J Pharm Res, March 2021; 20(3): 578 